\title{
ANALISIS HASIL BELAJAR MATEMATIKA PESERTA DIDIK PADA POKOK BAHASAN LINGKARAN BERDASARKAN RANAH KOGNITIF TAKSONOMI BLOOM
}

\section{ANALYSIS OF STUDENTS' MATHEMATICS LEARNING OUTCOMES ON THE CIRCLE SUBJECT BASED ON THE COGNITIVE DOMAIN OF BLOOM TAXONOMY}

\author{
Nur Yuliany1), Rukayyah2), Lisnasari Andi Mattoliang3), Andi Halimah"), Ilhamsyah ${ }^{\text {5) }}$ \\ 1,2,3,4)Fakultas Tarbiyah dan Keguruan Universitas Islam Negeri Alauddin Makassar \\ 5)Universitas Muhammadiyah Makassar \\ nur.yuliany@uin-alauddin.ac.id ${ }^{1}$, rukayyah@gmail.com ${ }^{2}$, lisnasari.mattoliang@uin- \\ alauddin.ac.id ${ }^{3}$, andi.halimah@uin-alauddin.ac.id ${ }^{4}$ ), ilhamsyah@unismuh.ac.id5)
}

\begin{abstract}
Abstrak
Tujuan dari penelitian ini adalah untuk mengetahui hasil belajar matematika peserta didik beserta faktor apa saja yang memberi pengaruh pada hasil belajar mereka pada materi lingkaran sesuai ranah kognitif taksonomi bloom. Penelitian ini merupakan jenis deskriptif kualitatif. Penentuan sampel didasarkan pada purposive sampling sehingga ditentukan sampel penelitian ialah seluruh siswa dalam kelas VIII di MTs Al-Ikhlas Addary DDI Takkalasi. Subjek penelitian berjumlah 29 orang. Data dikumpulkan melalui tes, wawancara, serta dokumentasi. Instrumen yang digunakan ialah tes dalam bentuk esai sebanyak 6 nomor yang sudah disesuaikan dengan tahapan: pengetahuan, pemahaman, analisis, penerapan, evaluasi, dan sintesis dari taksonomi bloom. Hasil yang didapatkan dari penelitian ini ialah hasil belajar siswa yang paling tinggi berada pada tahapan pemahaman, sementara hasil belajar siswa yang paling rendah berada pada tahapan evaluasi dan pengetahuan.
\end{abstract}

Kata Kunci: hasil belajar, lingkaran, ranah kognitif, taksonomi Bloom

\begin{abstract}
The purpose of this research is to know the mathematics learning outcomes of the students along with what factors influence their learning outcomes in the discussion circle according to the cognitive domain of bloom taxonomy. This research is a qualitative descriptive type. The determination of the sample was based on purposive sampling so that the research sample was determined to be all students in class VIII at MTs Al-Ikhlas Addary DDI Takkalasi. The research subjects were 29 people. Data were collected through tests, interviews, and documentation. The instrument used was a test in the form of a 6-number of essay which had been adjusted according to the stages: knowledge, understanding, analysis, application, evaluation, and synthesis of the bloom taxonomy. The results obtained from this study are that the highest student learning outcomes are at the understanding stage, while the lowest student learning outcomes are at the evaluation and knowledge stages.
\end{abstract}

Keywords: learning outcomes, circle, cognitive domain, Bloom's taxonomy

How to Cite: Yuliany, N., Rukayyah, Mattoliang, L. A., Halimah, A. \& Ilhamsyah. (2021). Analisis hasil belajar matematika peserta didik pada pokok bahasan lingkaran berdasarkan ranah kognitif taksonomi Bloom. Al asma: Journal of Islamic Education, 3(1), 38-49. 


\section{PENDAHULUAN}

Pendidikan merupakan salah satu aspek yang sangat berperan penting dalam peningkatan kualitas sumber daya manusia. Hal yang paling erat dengan kehidupan manusia ialah pendidikan. Pendidikan menjadi faktor yang begitu penting pada kepiawaian manusia dalam memecahkan permasalahan kehidupannya. Pendidikan juga dikatakan sebagai proses seseorang dalam mencari ilmu, pengalaman, serta budi pekerti (Yamin, 2009). Dengan proses ini sebuah bangsa akan mempunyai masyarakat yang bermutu jika pendidikannya mempunyai sistem yang bagus.

Matematika ialah ilmu yang pada dasarnya berdiri sendiri (bukan cabang dari ilmu alam). Terdapat banyak hal yang menjadi alasan pentingnya seseorang mempelajari matematika. Cockrof memaparkan bahwa matematika perlu diberikan kepada anak-anak (pelajar) sebab akan senantiasa digunakan pada semua aspek kehidupan, semua bidang studi sangat membutuhkan kepiawaian matematika yang sesuai, menjadi alat komunikasi yang meyakinkan, singkat, jelas, bisa diterapkan dalam penyajian informasi dengan beberapa cara, menambah kepiawaian berpikir logis, teliti, serta sadar keruangan dan memberikan rasa puas pada usaha menyelesaikan masalah (Suryawati \& Yulfikar, 2012). Oleh sebab itu, matematika menjadi ilmu pengetahuan yang penting dipelajari dan dipahami.

Matematika mempunyai peran yang sangat urgen, sehingga hal yang harus diperhatikan diantaranya mengenai usaha dalam meningkatkan prestasi belajar matematika yakni dengan mengamati beberapa hasil yang sudah dicapai, seperti dalam konteks kemampuan/kepiawaian siswa. Sasarannya ialah untuk mengetahui pencapaian dari proses pembelajaran itu. Sebagai usaha agar mengetahui tingkatan keberhasilan siswa dalam memenuhi tujuan pembelajaran, maka hasil evaluasi belajar mempunyai target tertentu yang termuat dalam tujuan pembelajaran itu.

Pembelajaran matematika tentunya diharapkan bisa berakhir dengan pemahaman yang ensiklopedis dan menyeluruh (lintas tema bahkan listas bidang ilmu apabila memungkinkan) mengenai penyajian materi (Abrar, 2016). Hasil belajar dari peserta didik bisa ditemukan dengan melakukan sebuah evaluasi (Angriani dkk., 2018). Sasaran diselenggarakannya evaluasi dalam pendidikan ialah guna mengetahui sampai di mana pengetahuan pelajar (mengetahui level kecerdasannya). Evaluasi bisa membantu bagi pihak guru juga sekolah untuk mengetahui kegiatan pembelajaran berhasil ataukah tidak, serta apakah proses pendidikan pada sekolah tersebut sudah baik atau belum (Halik dkk., 2019).

Pengklasifikasian tujuan pembelajaran mesti diselaraskan pada tiga domain yang menempel dalam diri seorang pelajar sebagaimana dipaparkan Benjamin S. Bloom atau dikenal dengan taksonomi bloom. Ketiga domain itu ialah ranah berpikir (cognitive domain), ranah nilai/sikap/perilaku (affective domain), serta ranah keterampilan (psychomotor domain) (Khasanah, 2015). Ranah-ranah tersebut ialah target atau aspek penilaian yang menjadi titik perhatian yang akan ditemukan statusnya sesuai pengukuran.

Ranah berpikir menjadi peran utama untuk ketuntasan hasil belajar para siswa dan digunakan dalam menentukan ketercapaian atau pun tidaknya target pembelajaran, sebab ranah ini berhubungan dengan kepiawaian mereka menguasai suatu pembelajaran. Ranah berpikir terdiri dari 6 tingkatan, yakni pengetahuan (knowledge), aplikasi (application), pemahaman (comprehension), sintesis (synthesis), analisis (analysis), serta 
evaluasi (evaluation). Bloom mengelompokkan level tipe hasil belajar pada ranah berpikir dalam 6 jenis, yakni pengetahuan, aplikasi, pemahaman, analisis, evaluasi, dan sintesis (Purwanto, 2006). Ranah berpikir memuat perilaku yang menitikberatkan aspek intelektual, misalnya pengetahuan juga kepiawaian dalam berpikir (Utari, 2010). Ranah berpikir merupakan sub taksonomi yang memaparkan keahlian mental yang selalu diawali dari level pengetahuan hingga level tertinggi yakni evaluasi.

Materi yang diputuskan menjadi topik penelitian ialah lingkaran. Materi ini dipilih sebab tergolong dalam materi yang belum bisa dimengerti dengan seksama oleh para pelajar. Sesuai hasil wawancara terbatas pada seorang guru matematika di MTs Al-Ikhlas Addary DDI Takkalasi yang mengatakan kurangnya siswa yang memahami materi ataupun soal-soal yang diberikan serta kurang kemampuan mengingat pelajar utamanya mengenai rumus dalam materi lingkaran, sehingga mereka belum bisa memahami materi tersebut dengan baik (Usman, 2017). Bisa dikatakan bahwa para pelajar yang mampu mengerti/paham pada materi cukup rendah, tiap pelajar mempunyai level kemampuan yang tidak sama, sehingga hasil belajar mereka tergolong rendah. Hal ini bisa dibuktikan dengan hasil ujian harian pada pembahasan lingkaran, 50\% dari pelajar mendapat nilai yang di bawah dari standar KKM. Alasan inilah yang memutuskan peneliti untuk menggali hal apa saja yang menjadi kesulitan para pelajar dalam memahami/mengerti materi lingkaran, sebab kemampuan mereka dalam materi ini khususnya pada kelas VIII B masih tergolong rendah.

Kurva yang tertutup sederhana dan menjadi tempat kedudukan beberapa titik dengan jarak sama pada suatu titik tertentu dinamakan sebagai lingkaran. Jarak yang sama dinamakan jari-jari, dan titik tertentu yang dimaksud dinamakan pusat dari lingkaran (Nuharini, 2008). Dalam definisi yang lain, bisa pula dikatakan bahwa lingkaran ialah suatu garis yang bentuknya lengkung dan kedua ujungnya bertemu, sementara titiktitik yang ada letaknya sama jauh dengan sebuah titik tertentu. Titik tertentu ini ialah pusat dari lingkaran, dan garis lengkung yang ujungnya bertemu ialah keliling dari lingkaran. Daerah yang dibatasi/dikontrol oleh lingkaran dinamakan bidang dari lingkaran.

Penelitian terkait analisis hasil belajar berdasarkan ranah pengetahuan dari taksonomi Bloom dilakukan sebelumnya oleh Oktaviana \& Prihatin (2018) dengan hasil penelitian bahwa hasil belajar dari para siswa jika disesuaikan ranah pengetahuan taksonomi bloom terbaru ialah para siswa lebih bisa mengerjakan soal pada indikator pemahaman sebesar 60\% dibandingkan soal dengan indikator menerapkan yakni 19,2\%. Selain itu, penelitian oleh Amelia dkk. (2016) memperoleh hasil bahwa hasil belajar matematika para siswa dengan materi himpunan berdasarkan taksonomi bloom ialah level pengetahuan/C1 92,5\%, level pemahaman/C2 61,2\%, serta level aplikasi/C3 71,2\%.

\section{METODE PENELITIAN}

Penelitian ini termasuk dalam jenis kualitatif dengan metode deskriptif. Metode ini adalah metode yang sasarannya ingin melukiskan dengan utuh serta mendalam tentang asas sosial dan bermacam-macam fenomena yang ada dalam masyarakat selaku subjek penelitian, sehingga diperlihatkan karakteristik, sifat, dan juga model dari kejadian itu (Sanjaya, 2015). MTs Al-Ikhlas Addary DDI Takkalasi yang ada di kabupaten Barru menjadi tempat diselenggarakannya penelitian ini. Alasan dipilihnya tempat ini: pertama 
dari hasil ujian mid semester para siswa, masih ada beberapa dari mereka yang nilainya di bawah Kriteria Ketuntasan Minimal (KKM). Kedua, lokasi tersebut mudah dijangkau oleh peneliti, dan ketiga, guru maupun siswa sangat responsif. Hal ini diperlihatkan saat peneliti mengadakan pengamatan awal, kedua pihak (guru dan siswa) sangat antusias dan menunjukkan respons yang baik dalam memberi informasi yang diperlukan peneliti.

Penelitian ini mengambil kelas VIII-B sebagai subjek penelitian yang jumlah siswanya ada 29 orang. Pemilihan subjek ini sebagai sampel didasarkan dengan purposive sampling. Selain itu alasan lain peneliti memilih kelas VIII-B sebab siswa yang ada di kelas ini lebih bervariasi, dalam artian masih terdapat siswa dengan intelektual tinggi hingga yang rendah. Alat ukur penelitian yang digunakan ialah tes, dokumentasi, juga interview (wawancara). Data yang terkumpul dianalisis dengan teknik reduksi data, penguraian data, penentuan kesimpulan, serta verifikasi.

\section{HASIL DAN PEMBAHASAN}

Untuk menyederhanakan analisis nilai dari hasil belajar para siswa dalam setiap tahapan dari ranah pengetahuan taksonomi bloom, peneliti menginputnya dalam tabel hasil jawaban para siswa yang dikelompokkan pada 3 kategori yakni salah, kurang sempurna, dan sempurna/benar.

Tabel 1. Hasil Jawaban Siswa Terhadap Soal Materi Lingkaran

\begin{tabular}{clllllll}
\hline \multirow{2}{*}{$\begin{array}{c}\text { No } \\
\text { urut }\end{array}$} & \multirow{2}{*}{ Nama Siswa } & \multicolumn{6}{c}{ No Soal } \\
\cline { 2 - 7 } 1 & AIN 1 & $\mathbf{1}$ & $\mathbf{2}$ & $\mathbf{3}$ & $\mathbf{4}$ & $\mathbf{5}$ & $\mathbf{6}$ \\
\hline 2 & AW 2 & $\mathrm{K}$ & $\mathrm{B}$ & $\mathrm{K}$ & $\mathrm{K}$ & $\mathrm{K}$ & $\mathrm{S}$ \\
3 & AZM 3 & $\mathrm{K}$ & $\mathrm{K}$ & $\mathrm{K}$ & $\mathrm{K}$ & $\mathrm{K}$ & $\mathrm{K}$ \\
4 & AB 4 & $\mathrm{K}$ & $\mathrm{K}$ & $\mathrm{K}$ & $\mathrm{K}$ & $\mathrm{K}$ & $\mathrm{K}$ \\
5 & FA 5 & $\mathrm{K}$ & $\mathrm{B}$ & $\mathrm{K}$ & $\mathrm{K}$ & $\mathrm{K}$ & $\mathrm{S}$ \\
6 & FU 6 & $\mathrm{K}$ & $\mathrm{K}$ & $\mathrm{K}$ & $\mathrm{K}$ & $\mathrm{B}$ & $\mathrm{K}$ \\
7 & HT 7 & $\mathrm{K}$ & $\mathrm{B}$ & $\mathrm{K}$ & $\mathrm{S}$ & $\mathrm{K}$ & $\mathrm{S}$ \\
8 & HA 8 & $\mathrm{K}$ & $\mathrm{B}$ & $\mathrm{K}$ & $\mathrm{S}$ & $\mathrm{K}$ & $\mathrm{S}$ \\
9 & IM 9 & $\mathrm{K}$ & $\mathrm{K}$ & $\mathrm{K}$ & $\mathrm{S}$ & $\mathrm{K}$ & $\mathrm{S}$ \\
10 & KA 10 & $\mathrm{K}$ & $\mathrm{K}$ & $\mathrm{K}$ & $\mathrm{K}$ & $\mathrm{K}$ & $\mathrm{K}$ \\
11 & KI 11 & $\mathrm{K}$ & $\mathrm{K}$ & $\mathrm{K}$ & $\mathrm{S}$ & $\mathrm{K}$ & $\mathrm{K}$ \\
12 & KK 12 & $\mathrm{K}$ & $\mathrm{K}$ & $\mathrm{K}$ & $\mathrm{S}$ & $\mathrm{K}$ & $\mathrm{S}$ \\
13 & KNA 13 & $\mathrm{B}$ & $\mathrm{B}$ & $\mathrm{B}$ & $\mathrm{B}$ & $\mathrm{B}$ & $\mathrm{B}$ \\
14 & MK 14 & $\mathrm{K}$ & $\mathrm{K}$ & $\mathrm{K}$ & $\mathrm{K}$ & $\mathrm{S}$ & $\mathrm{S}$ \\
15 & MINR 15 & $\mathrm{K}$ & $\mathrm{K}$ & $\mathrm{K}$ & $\mathrm{K}$ & $\mathrm{K}$ & $\mathrm{S}$ \\
16 & MR 16 & $\mathrm{K}$ & $\mathrm{K}$ & $\mathrm{K}$ & $\mathrm{K}$ & $\mathrm{K}$ & $\mathrm{S}$ \\
17 & NW 17 & $\mathrm{K}$ & $\mathrm{B}$ & $\mathrm{B}$ & $\mathrm{K}$ & $\mathrm{B}$ & $\mathrm{K}$ \\
18 & NL 18 & $\mathrm{K}$ & $\mathrm{K}$ & $\mathrm{K}$ & $\mathrm{K}$ & $\mathrm{S}$ & $\mathrm{S}$ \\
19 & NA 19 & $\mathrm{K}$ & $\mathrm{K}$ & $\mathrm{K}$ & $\mathrm{K}$ & $\mathrm{S}$ & $\mathrm{S}$ \\
20 & NAM 20 & $\mathrm{K}$ & $\mathrm{B}$ & $\mathrm{K}$ & $\mathrm{S}$ & $\mathrm{K}$ & $\mathrm{S}$ \\
21 & NFT 21 & $\mathrm{K}$ & $\mathrm{B}$ & $\mathrm{K}$ & $\mathrm{K}$ & $\mathrm{K}$ & $\mathrm{K}$ \\
22 & PA 22 & $\mathrm{K}$ & $\mathrm{B}$ & $\mathrm{K}$ & $\mathrm{K}$ & $\mathrm{B}$ & $\mathrm{K}$ \\
23 & RM 23 & $\mathrm{K}$ & $\mathrm{K}$ & $\mathrm{B}$ & $\mathrm{B}$ & $\mathrm{B}$ & $\mathrm{K}$ \\
24 & RA 24 & $\mathrm{K}$ & $\mathrm{K}$ & $\mathrm{K}$ & $\mathrm{S}$ & $\mathrm{B}$ & $\mathrm{S}$ \\
25 & SRH 25 & $\mathrm{K}$ & $\mathrm{B}$ & $\mathrm{B}$ & $\mathrm{K}$ & $\mathrm{K}$ & $\mathrm{S}$ \\
26 & SA 26 & $\mathrm{K}$ & $\mathrm{K}$ & $\mathrm{B}$ & $\mathrm{K}$ & $\mathrm{K}$ & $\mathrm{S}$ \\
27 & SN 27 & $\mathrm{S}$ & $\mathrm{K}$ & $\mathrm{B}$ & $\mathrm{S}$ & $\mathrm{S}$ & $\mathrm{S}$ \\
28 & SYN 28 & $\mathrm{K}$ & $\mathrm{K}$ & $\mathrm{S}$ & $\mathrm{S}$ & $\mathrm{S}$ & $\mathrm{S}$ \\
29 & ZJ 29 & $\mathrm{K}$ & $\mathrm{K}$ & $\mathrm{K}$ & $\mathrm{S}$ & $\mathrm{K}$ & $\mathrm{S}$ \\
\hline & & $\mathrm{K}$ & $\mathrm{K}$ & $\mathrm{K}$ & $\mathrm{K}$ & $\mathrm{S}$ \\
\hline
\end{tabular}




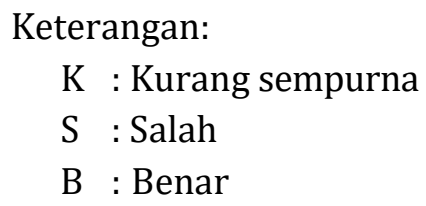

Tabel 2. Distribusi Frekuensi dan Persentase Kesulitan Siswa Tiap Tahapan

\begin{tabular}{llcc}
\hline No & Kategori Hasil Tiap Tahapan & Frekuensi & Persentase \\
\hline 1 & Tahap Pengetahuan & 28 & $96,551 \%$ \\
2 & Tahap Pemahaman & 19 & $65,517 \%$ \\
3 & Tahap Penerapan & 25 & $86,206 \%$ \\
4 & Tahap Analisis & 27 & $93,103 \%$ \\
5 & Tahap Sintesis & 23 & $79,310 \%$ \\
6 & Tahap Evaluasi & 28 & $96,551 \%$ \\
\hline
\end{tabular}

Perhitungan persentase hasil belajar pada butir soal menggunakan rumus berikut:

$$
P=\frac{f}{n} \times 100 \%
$$

Keterangan:

P: persentase hasil belajar

F: frekuensi siswa yang mengalami kesulitan

$\mathrm{N}$ : Jumlah siswa

Pencapaian pembelajaran peserta didik dalam fase ini masuk dalam kategori rendah, fase tersulit peserta didik yaitu dalam fase pengetahuan dan evaluasi sebesar 96,551\%. Dari hasil analisis pada tes siswa, hal paling sulit terjadi dalam tahapan pengetahuan dan evaluasi. Dalam tahapan pengetahuan, para siswa tidak bisa menjawab soal dengan benar ketika diperintahkan memperlihatkan jari-jari, mereka hanya bisa memperlihatkan 2 jari-jari, yang sebenarnya ada 3 jari-jari pada gambar. Jari-jari yang bisa diperlihatkan ialah jari-jari (r) yang ada pada diameter, jadi karena diameternya adalah $\overline{A D}$ dengan titik pusat $\mathrm{E}$, para siswa hanya bisa menjawab "r" ialah $\overline{E A}$ dan $\overline{E D}$, padahal masih ada garis $\overline{E C}$ sebagai jari-jari lingkaran. Selain jari-jari, hal yang sama juga terjadi pada busur lingkaran, para siswa hanya memperlihatkan apotema yang mana ialah $\widehat{C D}$ dan $\widehat{A C}$, mereka tidak memperlihatkan $\widehat{D A}$. Para siswa juga melakukan kesalahan lain ketika memperlihatkan apotema, di mana apotema dalam gambar lingkaran ialah $\overline{B E}$ tetapi mereka menunjuk salah satu dari tali busur atau jari-jari. Hal ini tidak sejalan dengan pernyataan R. Soejadi yakni definisi bisa membuat siswa mengilustrasikan atau menggambarkan atau melambangkan konsep dari definisi itu (Fatmawati, 2010). Karena separuh dari siswa bisa memaparkan jari-jari dengan benar namun tidak dalam menunjukkan gambar, mereka kesulitan sebab ambigu dengan soal, para siswa tidak mengetahui taktik penyelesaian soal, kurang memahami maksud soal, serta kurang sempurna menjawab soal sebab lupa menuliskan satuan dan kurang teliti saat menghitung. Hal ini diperkuat dengan hasil yang didapatkan Kartika, yakni siswa kesulitan dalam memecahkan masalah matematika karena belum bisa memahami permasalahan yang diberikan, sulit menentukan strategi yang tepat untuk menyelesaikan soal, dan sulit mengerjakan prosedur tematik dengan benar (Kartika, 2015). 
Beberapa faktor yang menjadi penyebab kesulitan siswa dalam tahap pengetahuan dan evaluasi ialah kurangnya pengetahuan dari para siswa pada bagian-bagian lingkaran, dan kurangnya kemampuan mereka membedakan berbagai komponen pada soal, sehingga para siswa tidak bisa menafsirkan dan menilai soal itu. Pada tahap ini hasil belajar siswa tinggi dibandingkan pada tahapan lain karena mengalami tingkat kesulitan siswa yang terendah yaitu pada tahap pemahaman yaitu $65,517 \%$

Soal yang berkaitan dengan tahapan pemahaman merupakan soal dengan level paling rendah dibanding soal yang lain. Soal ini menginstruksikan siswa untuk menguraikan tentang lingkaran, jari-jari, hingga diameter. Dari soal ini, mayoritas siswa bisa menguraikan dengan benar meski sebagian dari mereka menguraikan bahwa lingkaran ialah kurva yang tertutup sederhana dan jari-jari (r) ialah setengah dari diameter yang merupakan garis tengah dan berada tepat pada titik pusat lalu membagi 2 bagian. Jawaban ini belum sempurna. Hal ini karena para siswa kurang paham dengan definisi dari lingkaran, jari-jari, hingga diameter. Namun mereka bisa menunjukkan diameter dan jari-jari dengan benar. Hal ini membuktikan bahwa siswa kurang dalam hal pengetahuan komprehensi terjemahan. Padahal harapannya dalam tahapan ini testee bisa paham dengan arti/konsep, kondisi, dan fakta yang mereka ketahui (Purwanto, 2006).

Dalam fase menganalisis, mensintesis, dan mengevaluasi peserta didik tidak dapat melakukannya, peserta didik hanya melakukan penulisan angka yang terdapat dalam soal, ia kurang paham mengenai apa yang akan dilakukan pada angka tersebut dan terdapat beberapa peserta didik yang lembar jawabannya kosong tanpa menuliskan apapun.

Tahapan analisis dalam soal terdapat pada nomor keempat. Soal keempat masih terdapat beberapa siswa yang sulit menyelesaikannya. Soal keempat mencari luas dari lingkaran, namun siswa mencari keliling lingkaran. Sehingga Langkah pertama saja sudah terjadi kesalahan. Terdapat pula siswa yang sekedar mengurangkan tiap diameter tanpa mensubtitusikan beberapa komponen yang sudah ada pada soal. Dalam tahapan ini para siswa tidak bisa memilah komponen apa saja dalam soal, jadi bisa dikatakan sebagian dari mereka belum menguasai tahapan analisis. Karakteristik seorang siswa bisa menuntaskan level analisis ialah mereka bisa memilah, membagi, dan membedakan komponen atau unsur pembentuknya (Utari, 2010).

Tahapan sintesis ada dalam soal kelima. Soal kelima diselesaikan perlangkah yang sudah ditulis dalam soal itu, jadi para siswa diharapkan bisa mengisi tiap langkah itu dengan benar. Saat mengerjakan soal masih terdapat beberapa dari siswa yang kesulitan pada langkah kedua, di mana para siswa harusnya menuliskan " $r$ " kuadrat $\left(r^{2}\right)$ sesuai rumus dari luas lingkaran di langkah pertama. Contohnya dalam langkah pertama para siswa menulis $L=\pi r^{2}$, berarti seharusnya ketika langkah kedua mereka menuliskan $r^{2}=$ $\frac{L}{\pi}$, namun mereka menuliskan $r^{2}=r$.r. Sementara pada langkah ketiga seharunya $r=\sqrt{\frac{L}{\pi}}$, para siswa justru menulis $r=\frac{L}{2 \pi}$ bahkan ada yang $r=2 . r . \pi$. Kesulitan-kesulitan dalam tahapan ini disebabkan para siswa sering kali menyelesaikan soal dalam tahapan penerapan serta analisis. Hal ini dikuatkan dengan hasil penelitian dari Fatmawati di mana siswa yang berbuat kesalahan dalam tahapan sintesis disebabkan dari diri mereka yang cenderung menyelesaikan soal pada tahapan penerapan dan analisis (Fatmawati, 2010).

Tahapan evaluasi ada pada soal keenam. Dalam soal ini, para siswa mengalami kebingungan, sehingga mereka menjawab dengan cara membagi unsur-unsur dari 
lingkaran yang mereka ketahui ukurannya, diantaranya ialah lingkaran $A=K: \pi .2=$ 264: $\frac{22}{7}: 2=42$ dan lingkaran $B=L: \pi: 2=5544: \frac{22}{7}: 2=42$, kesimpulannya jari-jari (r) adalah sama. Semestinya siswa bisa menuliskan tiap langkah dengan benar dengan mencari jari-jari lingkaran A dan lingkaran B. Sehingga bisa didapatkan kesimpulannya kedua lingkaran mempunyai jari-jari yang sama. Dalam tahapan ini para siswa belum bisa dikatakan memenuhi, sebab mereka harus mampu memaparkan langkah penyelesaian dengan benar lalu membuat kesimpulan agar ciri-ciri untuk dikatakan tuntas yakni mengkritik, mengoreksi, menilai, membandingkan, dan membuktikan bisa terlaksana.

Peserta didik kurang cermat dalam menyelesaikan permasalahan sehingga apa yang ia hasilkan kurang baik yaitu peserta didik tidak melakukan perhitungan secara teliti dan ia lupa memberikan satuan dalam jawaban akhir mereka. Kurangnya ketelitian para siswa saat menjawab ada pada soal ketiga, keempat, dan keenam $(3,4,6)$. Meski terdapat beberapa siswa yang bisa mendapat akhir jawaban yang benar, namun mereka tidak memberi ukuran satuan dengan benar pada step terakhir. Menulis luas lingkaran $=7.546$. Dari jawaban tersebut, siswa hanya menulis hasil yang mereka dapat tanpa diikuti satuan. Siswa perlu dibiasakan untuk menuliskan unsur-unsur ketika mengerjakan soal hingga selesai, agar tidak ada kesalahpahaman. Kebiasaan para siswa juga bisa membantu mereka belajar dengan baik, seperti yang dikemukakan Pavlov bahwa konsep dari pembiasaan dalam hubungannya dengan belajar mengajar, supaya para siswa bisa belajar dengan baik. Adapun ketidaktelitian siswa terjadi ketika menghitung seperti luas lingkaran yang seharusnya $2464 \mathrm{~m}^{2}$ tetapi mereka menulis 1464 .

Dari pembahasan yang ada di atas, bisa diputuskan bahwa hasil belajar para siswa dalam materi lingkaran paling tinggi ada pada level pemahaman, di mana persentasenya yakni $65,517 \%$ adalah terendah dari tahapan yang lain.

Setelah melakukan koreksi lalu menganalisis hasil dari tes dan kegiatan wawancara secara langsung, santai, dan terbuka, maka peneliti mengetahui beberapa faktor yang menjadi pengaruh bagi hasil belajar matematika pada materi lingkaran, yakni:

a. Minimnya keinginan belajar matematika peserta didik

Keinginan atau minat belajar yaitu hal yang penting dalam pencapaian peserta didik saat proses pembelajaran, apabila dalam proses pembelajaran yang disertai dengan keinginan kuat dalam belajar akan berjalan dengan baik. Sebagai contoh ketiga peserta didik berikut dengan kode IM 9, SRH 25, SN 27. Mereka mengalami kesulitan menyelesaikan soal mengenai lingkaran disebabkan karena minimnya keinginan. Peserta didik dengan kode SRH 25 ia tidak belajar saat ingin ujian maka ia menyelesaikan ujiannya dengan meniru pekerjaan temannya, IM 9 juga minim keinginan saat belajar matematika, ia belajar ketika hanya menyelesaikan tugas rumah, sehingga ia tetap kesulitan menjabarkan materi mengenai lingkaran, SN 27 juga minim kenginan dalam belajar matematika hal tersebut terjadi karena ia sulit mengerjakan soal cerita serta tidak mengetahui rumus dalam menyelesaikan soal cerita tersebut. Berikut hasil cuplikan wawancara peneliti Bersama dengan peserta didik :

1) Hasil wawancara dengan siswa yang berkode IM 9

Peneliti : "Saat adik mengerjakan tes, apakah ada kendala?"

Siswa : :Ada kak, saya tidak bisa menjelaskan bagian-bagian dari lingkaran, saya juga kesulitan menghitung." 
Peneliti :"Memangnya adik tidak belajar di rumah?”

Siswa :"Tidak kak."

Peneliti :"jadi kapan biasanya baru adik belajar?"

Siswa : "Saat ada PR kak".

2) Hasil wawancara dengan siswa yang berkode SRH 25

Peneliti : :Saat adik mengerjakan tes, apakah ada kendala?"

Siswa : :Banyak kak, bahkan saya kesulitan menyelesaikan soal yang kakak beri."

Peneliti : :Lalu dapat jawabannya dari mana dik?"

Siswa : :Saya nyontek kak."

Peneliti :"Apakah adik belajar di rumah?"

Siswa : "Tidak kak".

Peneliti : "Kenapa tidak?"

Siswa : "Tidak mood kak"

3) Hasil wawancara dengan siswa yang berkode SN 27

Peneliti :"Bagaimana soalnya kemarin dik? Mudah kan?"

Siswa : :Agak sulit kak, saya bingung dengan soalnya."

Peneliti :"Adik suka belajar matematika?"

Siswa : :Agak suka kak."

Peneliti :"Apakah adik belajar di rumah?"

Siswa :"Belajar kak, tapi kadang saya juga kebingungan”.

b. Minimnya pemahaman peserta didik dalam matematika salah satunya dalam materi lingkaran.

Hal yang menyebabkan minimnya pencapaian pembelajaran peserta didik yaitu ia mengalami kesulitan saat menyelesaikan permasalahan mengenai materi lingkaran. Sebagai contoh kedua peserta didik berikut, peserta didik dengan Kode IM 9 dan SRH 25. Peserta didik IM 9 kebingungan dalam menyelesaikan soal terutama soal nomor 6, sedangkan SRH 25 mengalami kesulitan di seluruh soal. Berikut wawancara dengan kedua peserta didik tersebut :

1) Hasil wawancara dengan siswa yang berkode IM 9

Peneliti : :Diantara soal kemarin, soal ke berapa yang adik anggap sulit?"

Siswa : :Soal nomor 6 kak."

Peneliti : :Apa yang sulit dari soal nomor 6?"

Siswa : :Saya tidak paham dengan soalnya kak"

Peneliti : : :Selain nomor 6, ada lagi?"

Siswa : :Nomor 1 kak, saya kurang mengerti tentang busur, tali busur, dan apotema lingkaran".

2) Hasil wawancara dengan siswa yang berkode SRH 25

Peneliti : :Diantara soal kemarin, soal ke berapa yang adik anggap sulit?”

Siswa : :"Semuanya susah kak."

Peneliti : :Coba adik jelaskan apa itu jari-jari?"

Siswa : :Tidak tau kak."

Peneliti : :Loh, tidak tau?"

Siswa : :Iya kak". 
c. Minimnya pengetahuan atau daya ingat mengenai rumus ataupun pengertian dan bagian pada lingkaran.

Pengetahuan atau daya ingat yaitu daya yang bisa menyimpan, mereproduksi, dan menerima kembali tanggapan/pengertian. Minimnya pengetahuan akan berdampak pada kesulitan menuntaskan permasalahan dalam belajar matematika. Sebagai contoh ketiga peserta didik dengan kode IM , NFT 21, dan SN 27. Peserta didik tersebut lupa pada pengertian, bagian lingkaran serta tidak memberikan satuan dalam jawaban akhirnya (IM 9 dan NFT 21) , sedangkan SN 27 ia lupa pada rumus keliling dan luas pada lingkaran. Hal tersebut sesuai dengan hasil wawancara di bawah ini:

1) Hasil wawancara dengan kode IM 9

Peneliti : :Coba adik jelaskan tentang lingkaran”

Siswa : : :Lupa kak."

Peneliti : :Kalau begitu, bisa tidak adik tunjukkan yang mana jari-jari lingkaran dalam gambar ini (sambil menunjuk gambar yang ada di depan)"

Siswa : : :Yang ini kak, jari-jarinya yaitu AE."

Peneliti :"Hanya itu?"

Siswa : :Yang ini juga kak, DE".

Peneliti : :Sekarang coba jelaskan tentang jari-jari lingkaran"

Siswa : :Jari-jari setengah dari diameter"

Peneliti : : Ada pengertian jari-jari yang lain?"

Siswa : :Lupa kak"

Peneliti :"Sekarang adik tahu tidak apa yang kurang dari jawaban adik pada nomor 3? Adik tidak memberi satuan, kenapa?"

Siswa : :Lupa kak"

2) Hasil wawancara dengan siswa kode NFT 21

Peneliti :"Kenapa adik tidak menyelesaikan soal nomor 3, 4, dan 6 dengan benar?"

Siswa : : :hehehe saya lupa beri kuadrat kak (sambil menunjuk satuan luas pada jawaban soal-soal tersebut)"."

Peneliti : :Coba jelaskan mengenai busur lingkaran?”

Siswa : :Busur adalah................... lupa kak (sambil tersenyum).”

3) Hasil wawancara dengan siswa kode SN 27

Peneliti :"Apakah adik kesulitan dalam mengerjakan soal pada tes kemarin?"

Siswa : :Iya kak, susah semua soalnya”

Peneliti : : :Bagian mana yang susah dik?"

Siswa : :Rumusnya kak, saya tidak ingat."

d. Kurangnya perhatian dari keluarga.

Minimnya dukungan ataupun perhatian keluarga saat belajar, hal tersebut merupakan salah satu penyebab kesulitan dalam belajar matematika. Contoh yang terjadi pada ketiga peserta didik yaitu IM 9, NFT 21 dan SN 27. Peserta didik IM 9 kurang diperhatikan oleh orang tuanya, sehingga ia belajar saat ada tugas rumah yang diberikan oleh guru. Peserta didik NF 21 menyatakan bahwa ia tidak pernah disuruh oleh orang tuanya untuk belajar, motivasi yang kurang juga terjadi pada SN 27. Peserta didik tersebut 
minim motivasi dari kakak, karena disaat ia meminta bantuan dari kakaknya, kakanya tidak ingin membantunya karena sibuk. Berikut wawancara dengan peserta didik:

1) Hasil wawancara dengan siswa IM 9

$\begin{array}{ll}\text { Peneliti } & \text { :"Apakah adik belajar di rumah?" } \\ \text { Siswa } & \text { :"Belajar kak kalau ada PR." } \\ \text { Peneliti } & \text { :"Kenapa? Adik tidak ditegur sama mama nya?" } \\ \text { Siswa } & \text { :"Kadang-kadang kak." } \\ \text { Peneliti } & \text { :"Adik ikut les?" } \\ \text { Siswa } & \text { :"Tidak kak". }\end{array}$

2) Hasil wawancara dengan siswa NFT 21

Peneliti : :Suka belajar matematika?"

Siswa $\quad$ :"Tidak terlalu kak, kalua soalnya mudah suka, kalau susah saya kadang menjadi bingung"

Peneliti : :Kalau di rumah, adik sering mengulangi pelajaran dari sekolah?"

Siswa : :Jarang kak."

Peneliti :"Mama nya tidak marah?"

Siswa : :Tidak pernah disuruh kak".

Peneliti :"Kenapa?"

Siswa :"Sibuk kak, jarang di rumah"

3) Hasil wawancara dengan siswa SM 27

Peneliti : :Selalu belajar di rumah dik?"

Siswa : :Tidak kak."

Peneliti : :Sekali pun tidak pernah?"

Siswa : :Jarang sekali kak."

Peneliti :"Kenapa? Tidak suka dengan pelajarannya atau bagaimana?"

Siswa : :Susah matematika kak".

Peneliti :"Tidak ikut les?

Siswa :"Tidak kak".

Dari beberapa wawancara yang dilakukan terdapat beberapa hal yang menyebabkan peserta didik sulit dalam memecahkan materi lingkaran, Adapun faktor penyebabnya ialah faktor internal dan eksternal. Berikut penjelasan dari faktor tersebut:

1) Faktor Internal

a. Beberapa peserta didik minim keinginan dalam belajar, terutama dalam matematika. Peserta didik ada yang belajar ketika ada tugas rumah, beberapa bingung saat belajar sehingga ia memutuskan berhenti belajar, dan bahkan malas dalam belajar matematika.

b. Peserta didik minim pemahaman mengenai lingkaran, hal tersebut berdampak pada ketidakpahaman menyelesaian permasalahan pada lingkaran.

c. Minimnya pengetahuan pada pengertian, rumus, serta bagian pada lingkaran, hal tersebut akan berdampak dalam memecahkan masalah pada materi lingkaran.

d. Ketelitian peserta didik dalam melakukan perhitungan kurang, hal tersebut berdampak saat menuntaskan soal latihan kurang benar. 
2) Faktor eksternal

a. Minimnya dukungan ataupun perhatian keluarga.

b. Tidak mengikutkan pelajaran tambahan di luar jam sekolah, sehingga peserta didik hanya dapat mempelajari sebisanya saja tanpa bantuan seseorang.

\section{SIMPULAN}

Persentase pencapaian pembelajaran peserta didik dari tingkat kesulitan dalam memecahkan permasalahan yaitu pada fase pengetahuan $96,551 \%$ fase pemahaman $65,51 \%$, fase penerapan $86,206 \%$, fase analisis $93,103 \%$, fase sintesis $79,310 \%$ dan fase evaluasi 95,551\%. Adapun penyebab internal peserta didik dalam pembelajaran yaitu : 1) Minat dari peserta didik kurang; 2) Peserta didik minim pengetahuan mengenai lingkaran, sehingga kurang paham mengerjakan soal; 3) Pengetahuan pada rumus, pengertian, dan bagian lingkaran kurang; 4) Teknik dalam perhitungan peserta didik kurang. Selain itu, faktor eksternal yaitu: 1) Kurangnya dukungan dari keluarga; 2) Tidak mengikutkan les di luar jam sekolah, sehingga ia hanya belajar tanpa bantuan orang lain.

\section{DAFTAR PUSTAKA}

Abrar, A. I. P. (2016). Pembelajaran berdasarkan masalah suatu upaya untuk mengembangkan kemampuan pemahaman dan representasi matematik siswa. MaPan, 4(1), 1-10. https://doi.org/10.24252/mapan.2016v4n1a1

Amelia, D., Susanto, \& Fatahillah, A. (2016). Analisis hasil belajar matematika siswa pada pokok bahasan himpunan berdasarkan ranah kognitif taksonomi Bloom kelas VIIA di SMPN 14 Jember. Jurnal Edukasi, 2(1), 1-4. https://doi.org/10.19184/jukasi.v2i1.3402

Angriani, A. D., Nursalam, Fuadah, N., \& Baharuddin. (2018). Pengembangan instrumen tes untuk mengukur kemampuan pemecahan masalah matematika siswa. AULADUNA: Jurnal Pendidikan Dasar Islam, 5(2), 211-223. https://doi.org/10.24252/auladuna.v5i2a9.2018

Fatmawati, L. (2010). Analisis kesalahan siswa kelas VIII dalam menyelesaikan soal lingkaran menurut taksonomi Bloom di SMPN 1 Bonyolangu.

Halik, A. S., Mania, S., \& Nur, F. (2019). Analisis butir soal Ujian Akhir Sekolah (UAS) mata pelajaran matematika pada tahun ajaran 2015/2016 SMP Negeri 36 Makassar. Journal of Islamic Education, 1(1), 11-17. https://doi.org/https://doi.org/10.24252/asma.v1i1.11249

Kartika, S. M. (2015). Profil kesulitan siswa kelas VIII dalam memecahkan masalah matematika pada materi pokok sistem persamaan linear dua variabel.

Khasanah, S. (2015). Analisis hasil belajar peserta didik pada implementasi scintific approach dalam pembelajaran kimia materi koloid di kelas XI IPA SMA/MA.

Nuharini, D. (2008). Matematika konsep. Jakarta: Pusat Perbukuan.

Oktaviana, D., \& Prihatin, I. (2018). Analisis hasil belajar siswa pada materi perbandingan berdasarkan ranah kognitif revisi taksonomi Bloom. Buana Matematika: Jurnal Ilmiah Matematika dan Pendidikan Matematika, 8(2:), 81-88. https://doi.org/10.36456/buana_matematika.8.2:.1732.81-88

Purwanto, N. (2006). Prinsip-prinsip teknik evaluasi pengajaran. Bandung: Remaja Rosdakarya. 
Sanjaya, W. (2015). Penelitian pendidikan jenis metode dan prosedur (III). Jakarta: Kencana. Suryawati, \& Yulfikar. (2012). Kualitas tes dan hasil belajar matematika siswa kelas VIII SMP Negeri Banda Aceh Tahun Pelajaran 2011/2012. Jurnal Peluang, 1(1).

Usman. (2017). Wawancara.

Utari, R. (2010). Taksonomi Bloom, apa dan bagaimana menggunakannya? Tidak Diterbitkan.

Yamin, M. (2009). Desain pembelajaran berbasis tingkat satuan pendidikan (III). Jakarta: Persada Press. 